\title{
Karya Nașā’ih al- 'Ibād oleh Nawawi al-Bantani dan Sirāj al- Tälibīn oleh Ihsan Muhammad Dahlan al-Jampasi al-Kediri: Kajian Perbandingan Terhadap Metode Penulisan Hadith
}

\author{
The Works of Nașā'iḥ al-'Ibād by Nawawi al-Bantani and Sirāj \\ al-Ṭālibīn by Ihsan Muhammad Dahlan al-Jampasi al-Kediri: \\ A Comparative Research on the Methods of Writing the Hadith
}

\author{
Arwansyah Kirin \\ Department of Islamic Studies, Centre for General Studies and Co-Curricular, \\ Universiti Tun Hussein Onn Malaysia, 86400 Parit Raja, Batu Pahat, Johor, Malaysia. \\ arwansyah@uthm.edu.my \\ Faisal Husen Ismail \\ Department of Islamic Studies, Centre for General Studies and Co-Curricular, \\ Universiti Tun Hussein Onn Malaysia, 86400 Parit Raja, Batu Pahat, Johor, Malaysia. \\ faisalhu@uthm.edu.my \\ Abd Shakor Borham \\ Department of Islamic Studies, Centre for General Studies and Co-Curricular, \\ Universiti Tun Hussein Onn Malaysia, 86400 Parit Raja, Batu Pahat, Johor, Malaysia. \\ shakor@uthm.edu.my
}

DOI: https://doi.org/10.22452/usuluddin.vol48no1.2

\begin{abstract}
The book of Nașā'ih al-'Ibād by Nawawi al-Bantani and Sirāj al-Ṭālibīn by Ihsan al-Jampasi are one of the main references used in the Nusantara Archipelago on Islamic knowledge relating to religious advices and tasawuf. Both books contain many hadiths and yet they are not stated about the position of the hadith. Therefore, this study aims to identify the methods used in writing the hadith by Nawawi al-Bantani and Ihsan al-Jampasi in the book of Nașā'ị al-'Ibād and Sirāj al-Ṭālibīn. This study also compares the methods adopted by the two books in the writing of hadith. This is done to find the similarities and differences between the two methods. The method for this study is qualitative, through the use of library research and analysis design of the contents in the books of Nașā'ih al-'Ibād and Sirāj al-Ṭālibīn. This study had found that, there exists similarities in the method of writing the hadith in the book of Nașā'ị al-'Ibād and Sirāj al-Ṭālibīn, which is in the writing of hadith without a sanad and only stating the mukhrij of the hadith. Furthermore, the two books had also used lafaz (sighat) Qala' at the beginning of the hadith. Meanwhile, the differences that had been found in this study is such that Nawawi al-Bantani writes the hadith without a sanad by adding the rāwī a'lā at the stage of tabi'in and sahabah. Nawawi al-Bantani also uses the method riwayat bi al-lafẓi. In contrast, the approach used by Ihsan al-Jampasi is the usage of various sighat
\end{abstract}


(format) to deliver the hadith. This includes stating the source of the hadith and at times using the method riwayat bi al-ma 'na.

Keywords: Nașā'ị̣ al-'Ibād, Sirāj al-Ṭālibīn, The writings of Hadith, Nawawi al-Bantani, Ihsan al-Jampasi

\begin{abstract}
Abstrak
Kitab Nașā'iḥ al- 'Ibād oleh Nawawi al-Bantani dan Sirāj al-Ṭālibīn oleh Ihsan al-Jampasi merupakan antara beberapa kitab utama yang dirujuk di Nusantara dalam ilmu Islam berkaitan nasihat-nasihat agama dan tasawuf. Dalam kedua-dua kitab tersebut memuatkan banyak hadithhadith. Walau bagaimana pun, tidak dinyatakan tentang kedudukan hadith tersebut. Oleh kerana itu, kajian ini bertujuan melihat metodologi penulisan hadith oleh Nawawi al-Bantani dan Ihsan al-Jampasi dalam kitab Nașā'iḥ al-'Ibād dan Sirāj al-Ṭālibīn. Selain itu, kajian ini juga menganalisis perbandingan metode kedua-dua kitab tersebut bagi mengetahui titik persamaan dan perbezaan di antara metode-metode tersebut. Metodologi kajian ini adalah kualitatif melalui kaedah kepustakaan dan reka bentuk analisis kandungan kitab Nașā'ị̆ al- 'Ibād dan Sirāj al-Tâalibìn. Kajian ini mendapati bahawa wujudnya persamaan metode penulisan hadith dalam kitab Nașā'iḥ al-Ibād dan Sirāj alTălibīn iaitu penulisan hadith tanpa sanad dan hanya menyatakan mukhrïj hadith sahaja. Selain itu, keduanya menggunakan lafaz (sighat) qāla pada awal permulaan hadith. Manakala perbezaanya pula ialah Nawawi alBantani menulis hadith tanpa sanad dengan menambah rāwi a' $\bar{a}$ di peringkat tabi' in dan sahabat. Beliau turut menggunakan metode riwayat bi al-lafżi. Pendekatan Ihsan al-Jampasi pula menggunakan pelbagai sighat (format) untuk menyampaikan hadith, menyatakan sumber hadith dan kadang-kadang menggunakan metode riwayat bi al-ma 'nā.
\end{abstract}

Kata kunci: Nașāih al-'Ibād, Sirāj al-Ṭālibīn, penulisan hadith, Nawawi al-Bantani, Ihsan al-Jampasi

\title{
Pendahuluan
}

Pengkajian hadith di Nusantara belum mendapat perhatian yang besar sebagaimana dilakukan kepada ilmu-ilmu keislaman lain seperti ilmu fiqh mahupun usul fiqh. Namun begitu, kebelakangan ini, kajian hadith dari sudut sanad, matan dan 'ulüm al-hadìth dilihat semakin mendapat perhatian selari dengan keperluan menjaga sumber-sumber rujukan utama Islam. Para ulama Nusantara telah mengisi kelompangan ini dengan baik. Nawawi al-Bantani dan Ihsan al-Jampasi memberikan sumbangan besar berkaitan hadith. Malah, perbincangan hadith telah menjadi 
fenomena dan ianya semakin rancak berkembang secara formal mahupun tidak formal.

Nawawi al-Bantani merupakan seorang ulama terkemuka di Nusantara serta turut dikenali sebagai mufassir, pemikir dan fakih dalam bidang keilmuan Islam. Selain itu beliau mempunyai kepakaran dalam bidang hadith. Manakala, Ihsan al-Jampasi merupakan seorang ulama terkemuka dalam ilmu falak, fekah dan tasawuf. Kedua-dua ulama tersebut telah memberikan sumbangan keilmuan yang besar kepada perkembangan hadith khsususnya dan keilmuan agama Islam umumnya di Nusantara ${ }^{1}$. Justeru kajian ini dilakukan untuk mengulas metode penulisan hadith dalam karya utama kedua ulama di atas. Kedua kitab tersebut ialah Nașā'ih al'Ibād karya Nawawi al-Bantani dan kitab Sirāj al-Ṭālibīn karya Ihsan al-Jampasi. Kajian Seterusnya akan dibuat perbandingan metode penulisan hadith daripada kedua-dua kitab tersebut. Ini bertujuan untuk melihat metode penulisan hadith pada zaman mereka ke atas sumbangan perkembangan ilmu hadith.

\section{Latar Belakang Pengarang}

Nama sebenar Nawawi al-Bantani adalah Muhammad bin 'Umar bin 'Arabi bin 'Ali. Beliau terkenal dengan nama Muhammad Nawawi al-Shaykh al-Jawi al-Bantani ${ }^{2}$. Di Indonesia beliau lebih dikenali dengan panggilan K.H Nawawi Putra Banten ${ }^{3}$. Nawawi dilahirkan pada tahun $1230 \mathrm{H} / 1813 \mathrm{M}$ di kampung Tanara, Serang, Kecamatan Tirtayasa Kabubaten Banten, Jawa Barat Indonesia ${ }^{4}$ dan wafat ketika berusia 84 tahun, iaitu pada 24 Syawal 1314 H/1897 M di tempat tinggalnya yang terakhir di Shi' ib 'Alī Makkah $^{5}$. Nawawi al-Bantani adalah seorang tokoh ulama terkemuka, yang dipuji oleh Snouck Hurgronje sebagai penduduk setempat yang sangat rendah hati sarjana pada masanya, dan

\footnotetext{
Ishak Haji Suliaman, "Metodologi Penulisan Bulugh al-Marām Sebagai Kitab Hadīth al-Aḥkām", Jurnal Usuluddin 10 (1999), 1-20.

2 Yusuf 'Allan Sarkis, Mu'jam al-Matbü'ah al- 'Arabiyyah wa al-Mu'arrabah (Kaherah: Maktabah al-Thaqafah al-Dīniyyah, t.t.), 1881.

3 Karel A. Steenbrink, Beberapa Aspek Tentang Islam di Indonesia Abad ke 19 (Jakarta: Terjemahan Bulan Bintang, 1984), 117.

4 Chaidar, Sejarah Pujangga Islam Shaykh Nawawi Banteni (Jakarta: CV Sarana Utama, 1978), 5.

5 Rafi'uddin Ramli, Sejarah Hidup dan Silsilah Keturunan Shaykh Nawawi Banteni (Banten: Yayasan Nawawi Tanara, t.t.), 7.
} 
penulis yang produktif dalam berbagai disiplin ilmu. Bahkan hari ini, banyak bukunya dipelajari di pesantren di Indonesia dan wilayah Nusantara lainnya.

Menurut satu sumber, Nawawi al-Bantani telah berjaya menghasilkan 99 buah karya penulisan, manakala menurut sumber lain menyatakan bahawa hasil karya beliau mencapai 115 buah yang mencakupi pelbagai bidang disiplin ilmu 6 . Di Indonesia, karya-karya Nawawi al-Bantani boleh didapati di kedai-kedai buku yang ada di kota-kota ${ }^{7}$. Berdasarkan hasil penelitian yang dilakukan oleh Martin Van Bruinessen ke beberapa pesantren di Indonesia, bahawa Nawawi al-Bantani menulis tidak kurang daripada 40 buku, ianya masih banyak diguna pakai sebagai materi pembelajaran di pesantren Indonesia ${ }^{8}$. Di samping itu, tidak kurang daripada 22 buah hasil karya Nawawi al-Bantani masih tersebar secara meluas, manakala 11 buah kitab karyanya adalah termasuk dalam kumpulan 100 kitab yang paling banyak digunakan di pesantren ${ }^{9}$. A.H Johns mendapati bahawa kesemua hasil karya beliau adalah dalam bahasa Arab yang sederhana. Hal ini mungkin kerana ia sesuai dengan tahap kemampuan masyarakat Nusantara dalam memahami bahasa Arab, selain itu kitab-kitab beliau banyak digunakan di Nusantara ${ }^{10}$.

Karya-karya Nawawi al-Bantani juga di pelajari disekolahsekolah agama Mindanou (Filipina Selatan) dan Thailand Selatan. Menurut Ray Salam T. Mangondaan, peneliti di Institute Studi Islam University of Philipines, karya Nawawi al-Bantani banyak dipelajari di sekolah agama Filipina Selatan yang masih menggunakan sistim pembelajaran Tradisional ${ }^{11}$. Keunggulan Nawawi al-Bantani tidak hanya diakui di negaranya tetapi juga di dunia Arab. Beliau dikenali melalui karyanya dalam bahasa Arab dalam pelbagai disiplin ilmu. Melalui karya-karyanya yang

6 Ensiklopedia Islam (cet. ke 3, Jakarta: PT, Ichtiar Baru Van Hoeve, 1994), $4: 24$

7 Ensiklopedia Islam, 59-65.

8 Martin Van Bruinesen, terj. Kitab Kuning (Pesantren dan Tarekat) (Bandung: Mizan, 1995), 239.

9 Martin Van Bruinesen, terj. Kitab Kuning (Pesantren dan Tarekat), 38.

10 A.H Johns, Qur'anic Exegesis in the Malay Word (t.tp.: t.p, .t.t.), 3.

11 Agus Sutopo, "Sumbangan Nawawi al-Bantani dalam Bidang Hadis: Kajian Terhadap Kitab Tanqih al-Qawl" (Disertasi, Jabatan al-Quran dan al-Hadith, Akademi Pengajian Islam, Universiti Malaya, 2008), 53. 
tersebar luas, justeru nama Nawawi al-Bantani termasuk dalam kategori ulama terkenal pada abad 14 H/19 M Dia digelar sebagai al-Imām Muhaqqīq wa Fahm Mudaqqīq dan digelari juga sebagai Imām Nawāwì al-Thānī. ${ }^{12}$ Gelaran-gelaran lain yang diberikan kepada beliau ialah Ulamā' al-Hijāz, Imām Ulamā' al-Haramayn, salah seorang Fuqahā' dan Hukamā' al-Muta'ākhirin dan mahaguru pada Nasr al-Ma'ārif Dìniyyah di Makkah. ${ }^{13}$ Hamka menyebut bahawa Nawawi al-Bantani merupakan tokoh ulama besar diawal abad ke empat belas hijrah atau dipenghujung abad ke tiga belas. K.H DR. Idham Chalid pernah memuji beliau dengan menyatakan bahawa karangan Nawawi al-Bantani mencakupi seluruh bidang disiplin ilmu yang sangat diperlukan oleh umat Islam di Indonesia. Oleh itu, beliau berhak mendapat gelaran 'pujangga dunia' 14 .

Sebagai bukti akan keagungan dan kemasyhuran Nawawi alBantani, nama dan keperibadian beliau telah disenaraikan bersama tokoh-tokoh terkemuka dunia dalam beberapa kitab biografi, seperti Kamus al-Munjid karya Louis Ma'luf ${ }^{15}$, Mu'jam al-A'lam yang dihimpun oleh Bassam Wahhab al-Jabi, Mu'jam al-alMatba'ah al-'Arabiyyah wa al-Mu'arrabah karya Yusuf 'Aliyah Sarkis, First Encyclopaedia of Islam karya E.J. Brill's dan lebih terperinci lagi dalam Mecca in the Later Part of the Nineteenth Century karya C.S. Hurgronje. Melalui karya-karyanya beliau dikenal sebagai Mufassir, pemikir dan Faqih. Kehebatan ilmunya tidak hanya mencakup dalam bidang tafsir, tauhid, fiqh dan tasawuf. Dia juga seorang sarjana hadith dan telah menulis karya khusus dalam bidang hadith di antaranya ialah Tanqih al-Qawl alHadìth Sharh al-Lubāb al-Hadìth. Selain itu, dalam karyakaryanya yang lain beliau juga menggunakan banyak hadith sebagai rujukan dan memperkuat hukum dalam debat dan diskusi salah satunya adalah kitab Nașā'ih al-'Ibād.

Ihsan Muhammad Dahlan al-Jampasi al-Kediri atau nama sebenar beliau adalah Bakri lahir pada tahun 1901 dan meninggal

12 Asnawi, "Pemikiran Shaykh Nawawi Tentang Ayat Qada' dan Qadar dalam Kitab Tafsirnya Marah Labib" (Disertasi IAIN Syarif Hidayatullah, Jakarta, 1989), 38.

13 Ensiklopedia Islam Indonesia (Jakarta: Depdikbud Indonesia, 1993), 2:845.

${ }^{14}$ Chaidar, Sejarah Pujangga Islam Shaykh Nawawi Banteni, vi.

15 Louis Ma'luf, Munjid fi al-A'lam (cet. ke 26, t.tp : t.p, t.t.), 581. 
dunia pada hari Isnin, 25 Zulhijjah $1371 \mathrm{H}$ bersamaan bulan September 1952 di Jampes, Kediri ${ }^{16}$. Bapa beliau bernama Kiyai ${ }^{17}$ Haji Dahlan manakala ibunya bernama Nyai Artimah ${ }^{18}$. Ihsan juga seorang ulama Nusantara yang hebat. Pada usia 29 beliau telah menulis kitab Tasrif al-'Ibarat, sebuah kitab dalam bidang ilmu falak. Kemudian pada usia 31 tahun, beliau telah menyelesaikan salah satu karya terbesar, iaitu kitab Sirāj al-Tâalibìn yang diterbitkan pada tahun 1936 oleh penerbit dan percetakan Banhaniyah di Surabaya yang bekerja sama dengan sebuah percetakan di Kaherah, Mesir, Musțafā al-Bābī Halabì.

Kitab ini dipelajari di beberapa universiti dan digunakan oleh hampir seluruh pondok pesantren di Indonesia dengan kajian mendalam tentang tasawuf dan akhlak. Kitab Sirāj al-Tălibìn juga dikaji oleh beberapa universiti di Timur Tengah, bahkan Raja Faruk daripada Mesir meminta Ihsan al-Jampasi menjadi tetamu kehormat Mesir untuk menjadi pengajar di Universiti al-Azhar. Namun Ihsan al-Jampasi menolaknya dengan baik kerana beliau memilih untuk mengajar di Pesantren Jampes Kediri.

Kitab Sirāj al-Tāalibìn ini bahkan menjadi rujukan wajib di pelbagai universiti di Eropah, Amerika dan Kanada pada jurusan teologi dan teosofi ${ }^{19}$. Melalui karyanya, beliau dikenal sebagai ahli ilmu falak, fiqh, dan tasawuf. Beliau mungkin tidak masyhur sebagai ahli atau sarjana hadith, tetapi beliau memiliki karya yang banyak menggunakan hadith sebagai rujukan dan panduan bagi orang yang membacanya. Di antaranya yang terkenal adalah kitab Sirāj al-Tâlibīn (syarah dari kitab Minhāj al-'Ābidīn karya alGhazālī). Kitab ini menghuraikan masalah-masalah tasawuf dengan kajian yang amat luas. Dalam mukaddimah kitab, Ihsan alJampasi memberikan huraian bahawa kitab ini disusun berdasarkan pengumpulan dan pindaan daripada pandanganpandangan ulama yang pakar dalam bidang tasawuf. Dalam syarahan pula, beliau banyak menukil hadith-hadith Sahīh alBukhārī, Saḥịh Muslim, Sunan al-Tirmidhī, Sunan al-Nasā̄ì,

\footnotetext{
Louis Ma'luf, Munjid fi al-A'lam, 25.

17 Gelaran bagi alim ulama Islam dan orang yang berpengetahuan tinggi dalam hal-hal agama Islam. Lihat Kamus Dewan Edisi ke-3 (Kuala lumpur: Dewan Bahasa dan Pustaka, 2002), 675.

18 Ihsan al-Jampasi, Pengantar Kitab Kopi dan Rokok (Yogyakarta: Pustaka Pesantren, 2009), 3.

19 Ihsan al-Jampasi, Pengantar Kitab Kopi dan Rokok, 18.
} 
Sunan Ibn al-Mājah, al-Mustadrak al-Hākim dan kitab hadith lainnya bagi penjelasan matan kitab. Beliau juga mengambil pandangan daripada beberapa pakar ilmu rijal bagi menentukan hukum sesebuah hadith.

Sumbangan Ihsan kepada masyarakat Muslim di Indonesia bahkan masyarakat dunia adalah amat besar. Sebagai seorang ulama, Shayh Ihsan telah menumpukan seluruh perhatian, pemikiran dan tenaga beliau bagi mengabdikan diri kepada santri dan pesantren serta masyarakat. Karya-karya beliau telahpun menjadi bacaan dan rujukan para pelajar juga masyarakat. Ihsan tidak melupakan masyarakat awam. Beliau dikenal memiliki ilmu hikmah dan menguasai ketabiban. Hampir setiap hari, beliau memberikan masanya untuk menerima tetamu dari pelbagai daerah bagi memberikan rawatan dan pengubatan serta bantuan lain. Pada masa revolusi fisik 1945, Ihsan juga memiliki banyak membantu perjuangan bangsa. Pondok Pesantren Jampes selalu menjadi tempat singgah para pejuang yang hendak menyerang Belanda. Bahkan, beberapa kali Ihsan turut menghantar pelajarpelajar beliau untuk ikut berjuang membela tanah air $^{20}$.

\section{Skop dan Metodologi}

Kajian ini memfokuskan kepada dua karya ulama Nusantara iaitu kitab Nașā'ih al-'Ibād oleh Nawawi al-Bantani dan Sirāj alTălibìn oleh Ihsan al-Jampasi. Nașā'ih al-'Ibād mengandungi 325 hadith, manakala Sirāj al-Ṭălibīn tidak dapat dipastikan jumlah hadith di dalamnya. ${ }^{21}$ Metodologi kajian yang digunakan adalah kualitatif melalui metode perpustakaan. Reka bentuk yang dipilih adalah analisis kandungan buku Nașā'ịh al-'Ibād dan Sirāj alTâalibìn yang ditulis oleh Nawawi al-Bantani dan Ihsan al-Jampasi. Sumber kedua adalah buku-buku, jurnal, majalah, makalahmakalah dan sumber lain yang berkaitan. Ini bagi mengumpul maklumat berkaitan metode penulisan hadith yang terdapat dalam karya kedua-dua ulama tersebut.

20 Ihsan al-Jampasi, Pengantar Kitab Kopi dan Rokok, 20.

21 Perlu dijelaskan di sini bahawa penelitian terhadap hadith-hadith yang terdapat dalam kitab Siraj al-Talibin masih jarang dilakukan orang, susunan letak penulisan haditnya masih sederhana dan tidak tersusun rapi, oleh itu amat susah bagi pengkaji untuk menghitung jumlah hadith yang terdapat dalam kitab tersebut) meskipun begitu jumlah hadith yang terdapat dalam kitab tersebut cukup banyak. 


\section{Hasil Dapatan}

Dapatan kajian daripada kitab Nașā'ih al-'Ibād dan Sirāj alTaălibin akan dibentangkan dalam jadual berikut:

Jadual 1.0: Metode penulisan hadith dalam kitab Nașā'ih al-'Ibād oleh Nawawi al-Bantani dan Sirāj al-Tāalibìn oleh Ihsan al-Jampasi

\begin{tabular}{|c|c|c|c|}
\hline No & Aspek & Kitab Nașā'iḥ al-'Ibād & Kitab Sirāj al-Ṭālibīn \\
\hline 1 & $\begin{array}{l}\text { Penu- } \\
\text { lisan } \\
\text { sanad }\end{array}$ & $\begin{array}{l}\text { 1. Menggunakan kaedah } \\
\text { penulisan hadith tanpa } \\
\text { Sanad }^{22} \text { dan hanya } \\
\text { menyebut perawi (Mukhrīj } \\
\text { al-Hadīth) })^{23} \text { yang menge- } \\
\text { luarkan hadith tersebut. } \\
\text { 2. Menulis hadith tanpa } \\
\text { menggunakan sanad, hanya } \\
\text { meletakkan Rāwi al-a'la di } \\
\text { peringkat tabi'in dan } \\
\text { sahabat. }\end{array}$ & $\begin{array}{l}\text { 1. Menggunakan kaedah } \\
\text { penulisan hadith tanpa } \\
\text { sanad hanya menyebut } \\
\text { Muhkrīj al-Hadith sahaja. }\end{array}$ \\
\hline 2 & $\begin{array}{l}\text { Penggu- } \\
\text { naan } \\
\text { lafaz dan } \\
\text { sighat } \\
\text { dalam } \\
\text { riwayat } \\
\text { hadith }\end{array}$ & $\begin{array}{l}\text { 1. Menggunakan kaedah } \\
\text { penulisan hadith hanya } \\
\text { dengan Sighat Ruwiya al- } \\
\text { Marfü' ilā al-Nabī. } \\
\text { 2. Menggunakan lafaz atau } \\
\text { sighat ruwiya dan qāla. } \\
\text { 3. Menggunakan lafaz atau } \\
\text { sighat fi al-Khabar. }\end{array}$ & $\begin{array}{l}\text { 1. Menggunakan kaedah } \\
\text { penulisan hadith dengan } \\
\text { menulis lafaz al-ladhì qül } \\
\text { fih di awal hadith. } \\
\text { 2. Menggunakan lafaz dan } \\
\text { sighat amala bi-qawlih } \\
\text { sallā Allāh 'alayh wa-sallam. } \\
\text { 3. Menggunakan lafaz dan } \\
\text { sighat qăl sallā Allāh } \\
\text { 'alayh wa-sallam. } \\
\text { 4. Menggunakan lafaz dan } \\
\text { sighat 'amal bi-khabar. } \\
\text { 5. Menggunakan lafaz dan } \\
\text { sighat qawluh sallā Allāh } \\
\text { 'alayh wa-sallam sahaja. }\end{array}$ \\
\hline
\end{tabular}

22 Sanad ialah rangkaian atau rantai-rantai perawi-perawi yang boleh menyampaikan kepada matan hadith.

${ }^{23}$ Mukhrij ialah makna harfiah kata Mukharrij yang berasal dari kata Kharraja ertinya orang yang mengeluarkan. Makna tersebut juga boleh didatangkan dari kata Akhraja dengan isim fa'ilnya Mukhrij. Menurut para ahli hadith, yang dimaksud dengan Mukhrij atau Mukharrij iaitu orang yang berperanan dalam mengumpul hadith, atau orang yang menyebutkan perawi hadith atau orangorang yang telah berhasil menyusun kitab berupa kumpulan hadith, seperti alBukhari, Muslim, Malik, Ahmad, dan lain-lain. 


\begin{tabular}{|c|c|c|c|}
\hline No & Aspek & Kitab Nașā'iḥ al-'Ibād & Kitab Sirāj al-Ṭālibīn \\
\hline & & & $\begin{array}{l}\text { 6. Menggunakan lafaz wa- } \\
\text { qad warada. } \\
\text { 7. Menggunakan lafaz wa- } \\
\text { Sāhib al-Shar'yaqūl. } \\
\text { 8. Menggunakan lafaz alā } \\
\text { tasma' qawluh al-Nabì } \\
\text { sallā Allāh 'alayh wa- } \\
\text { sallam. }\end{array}$ \\
\hline 3 & $\begin{array}{l}\text { Pernya- } \\
\text { taan } \\
\text { sumber } \\
\text { hadith }\end{array}$ & & 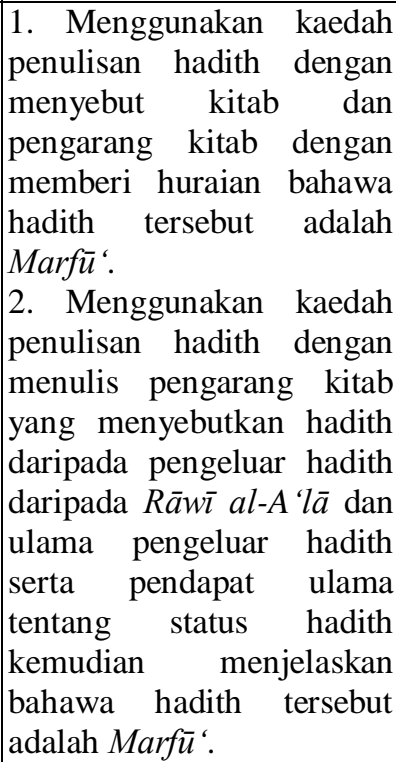 \\
\hline 4 & $\begin{array}{l}\text { Penu- } \\
\text { lisan } \\
\text { matan } \\
\end{array}$ & $\begin{array}{l}\text { 1. Menggunakan kaedah } \\
\text { penulisan hadith dengan } \\
\text { matan hadith sahaja. }\end{array}$ & \\
\hline 5 & $\begin{array}{l}\text { Penu- } \\
\text { lisan } \\
\text { makna } \\
\text { hadith }\end{array}$ & & $\begin{array}{l}\text { 1. Menggunakan kaedah } \\
\text { penulisan hadith dengan } \\
\text { menyebut } \\
\text { sahaja. }\end{array}$ \\
\hline
\end{tabular}

\section{Perbincangan}

Berdasarkan jadual di beri didapati bahawa terdapat persamaan dan perbezaan metode penulisan hadith dalam kitab Nașā'ih al'Ibād oleh Nawawi al-Bantani dan Sirāj al-Țālibìn oleh Ihsan alJampasi. Perbincangan berkaitan perkara ini seperti berikut: 


\section{i. Aspek penulisan Sanad}

Daripada jadual di atas, Nawawi al-Bantani menggunakan tiga metode iaitu:

Pertama: penulisan hadith tanpa sanad dan hanya menyebut perawi (Mukhrij al-Hadīth), contohya ${ }^{24}$ :

$$
\begin{aligned}
& \text { روى أنه صلى الله عليه وسلم قال: اللهم إني أسألك نفسا مطمئنة تؤمن بلقائك } \\
& \text { وترضى بقضائك وتقنع بعطائك (رواه الطبرانى). }
\end{aligned}
$$

Kedua: menulis hadith tanpa sanad dan hanya menyebut Rāwī al-a 'lā daripada Tabi' in, contohnya ${ }^{25}$ :

$$
\text { قال صلى الله عليه وسلم: حب الدنيا رأس كل خطيئة (رواه البيهي عن الحسن البصرى). }
$$

Ketiga: penulisan hadith tanpa sanad dan hanya menyebutkan Rāwì al-a 'lā diperingkat Sahabat, contohnya ${ }^{26}$ :

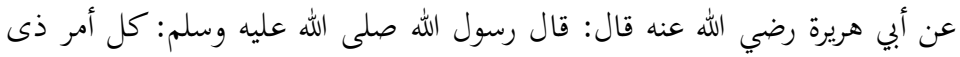

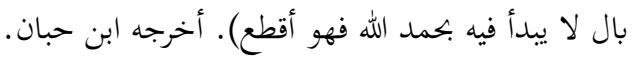

Ada kalanya beliau menyebutkan nama sahabat pada akhir matan hadith setelah disebutkan perawi yang mengeluarkan hadith tersebut. Contohnya ${ }^{27}$ :

$$
\begin{aligned}
& \text { قال النبي صلى الله عليه وسلم: ستة لعنتهم ولعنهم الله تعالى وكل نبي مجاب الدعوات }
\end{aligned}
$$

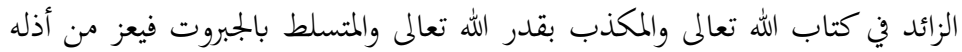

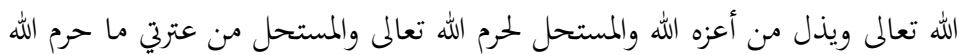

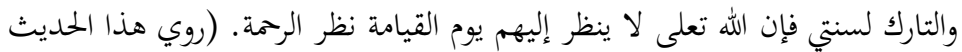

$$
\begin{aligned}
& \text { الترمذي والحاكم عن عائشة والحاكم عن علي). }
\end{aligned}
$$

Manakala Ihsan al-Jampasi hanya menggunakan satu metode sahaja iaitu kaedah penulisan hadith tanpa sanad dan hanya menyatakan Muhkrīj al-Hadīth, contohnya ${ }^{28}$ :

${ }^{24}$ Muhammad Nawawi Banteni, Nasā'ih al-'Ibād fì Bayān Alfāz Munabbihat 'alā al-Isti'dad li Yawm al-Ma'ad (Indonesia: Dār Ihta' al-Kutub al'Arabiyyah, t.t.), 30.

25 Nawawi, Nasā'ih al- 'Ibād fì Bayān Alfāz Munabbihat 'alā al-Isti'dad li Yawm al-Ma'ad, 30-32.

${ }^{26}$ Nawawi, Nasā'ih al- 'Ibād fì Bayān Alfāz Munabbihat 'alā al-Isti'dad li Yawm al-Ma'ad, 33.

27 Nawawi, Nasā'ih al- 'Ibād fì Bayān Alfāz Munabbihat 'alā al-Isti'dad li Yawm al-Ma'ad, 40. 


$$
\text { وأرسل جبريل الباب الجنة فقال أنظر اليها. }
$$

Daripada aspek pertama ini menunjukkan bahawa Nawawi alBantani dan Ihsan al-Jampasi sama-sama menggunakan kaedah penulisan hadith tanpa sanad dan hanya menyatakan mukhrij alhadīth sahaja, bezanya Nawawi al-Bantani menambahkan rāwī alA ' $l \bar{a}$ diperingkat Tabi' in dan Sahabat sedangkan Ihsan al-Jampasi tidak menggunakannya. Penulisan seperti ini selari dengan metode yang banyak digunakan oleh ulama-ulama di Nusantara pada abad ke $14^{29}$. Menurut kajian Ahmad Levi, metode penulisan hadith tanpa sanad oleh ulama Nusantara pada masa ini bukanlah bermakna ulama-ulama ketika itu mengabaikan kepentingan sanad. Namun ianya bertujuan untuk meringkaskan penulisan agar lebih mudah dan fokus dalam diskusi dan perdebatan ${ }^{30}$. Penulisan hadith tanpa sanad bukan hanya terdapat dalam bidang hadith sahaja, dalam bidang tafsir juga banyak digunakan oleh mufassir terutama mufassir melayu (Nusantara) ketika mereka meletakkan hadith-hadith sebagai penyokong bagi ayat-ayat al-Quran yang mereka tafsirkan misalnya H. Zainuddin Hamidy dalam karyanya Tafsir Qur'an, Abd Ra'uf al-Fansuri dalam karyanya Tarjuman alMustafid dan Haji Abd al-Halim Hasan dalam Tafsir al-Qur'an alKarim $^{31}$.

Sanad atau Tarīq ialah rangkaian riwayat yang menghubungkan matan hadith kepada Nabi saw ${ }^{32}$. Sanad adalah suatu keistimewaan umat Islam yang tidak ada pada umat-umat terdahulu. Prihatin terhadap sanad dalam menyampaikan berita (hadith) adalah suatu sunnah yang amat dituntut dan merupakan

${ }^{28}$ Nawawi, Nasā'ih al-'Ibād fì Bayān Alfāz Munabbihat 'alā al-Isti'dad li Yawm al-Ma'ad, 32.

29 Badri Khaeruman, "Perkembangan Hadis di Indonesia pada Abad XX", Diroyah: Jurnal Studi Ilmu Hadis 1, no 2 (March 2017), 187-202.

30 Fachrul Avivy, Ahmad Levi dan Jawiah Dakir, "Methodology of Writing Hadith in the Works of Muhammad Nawawi Al-Bantani" Journal of Applied Sciences Research 8, issue 4 (April 2012), 2187-2192.

31 Parlindungan Simbolon, "Metode Penulisan Hadith dalam Tafsir Bahasa Melayu: Kajian Perbandingan Antara Tafsir al-Misbah dan Tafsir Pedoman alMuttaqin" (Disertasi, Universiti Malaya, Kuala Lumpur 2013), 26-27.

32 Muḥammad 'Ajjāj al-Khātib, Ușūl al-Hadīth 'Ulumuh wa Muștalaḥuh (cet. ke-3, Beirut: Dār al-Fikr, 1975), 32-33. 
suatu syiar umat ini. Oleh yang demikian wajiblah setiap Muslim bersandar kepada sanad dalam menyampaikan hadith begitu juga dalam menulis hadith. Perletakan sanad dalam penulisan dan pengkajian hadith pada amnya bukan hanya berfungsi untuk mengesahkan kedudukan hadith sahaja tetapi ianya juga berfungsi sebagai nilai spiritual ${ }^{33}$. Oleh itu penulisan sanad dalam sesebuah hadith akan memudahkan untuk mengesan apakah hadith tersebut

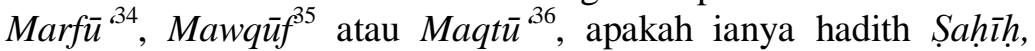
Da îf atau Maw $\bar{u}^{\prime}$ '. Jika ianya tidak ditulis maka akan sukar untuk memastikan kesahihan dan keda'ifan sesebuah hadith tersebut ${ }^{37}$.

Ibn al-Mubārak pernah mengatakan bahawa sanad adalah sebahagian (syiar) agama, kalaulah tidak kerana adanya sanad nescaya orang akan berkata apa saja yang mereka mahu ${ }^{38}$ dan yang memisahkan antara kami dengan golongan yang tidak dapat dipercaya riwayatnya adalah $\operatorname{sanad}^{39}$. Al-Nawāwī (pengarang kitab Arbā'in al-Nawāwì) ketika mengulas pernyataaan Ibn alMubārak di atas mengatakan bahawa bila sanad hadith berkualiti sahih maka hadith itu dapat diterima sedangkan bila tidak sahih maka harus ditinggalkan. Beliau menyatakan bahawa hubungan hadith dengan sanadnya seumpama hubungan antara haiwan dengan kakinya, oleh itu keduanya tidak boleh dipisahkan sama ada semasa menyampaikan hadith mahupun semasa menuliskan hadith $^{40}$.

33 Arif Chasanul Muna, Penulisan Kitab al-Sabat dalam Kajian Hadis di Nusantara (Kertas pembentangan, $1^{\text {st }}$ ASILHA International Conference: Hadith Studies and Its Contribution for Indonesia and Muslim World di UIN Sunan Kalijaga Yogyakarta, 26 Oktober 2016).

${ }^{34} M a r f \bar{u}$ ' ialah hadith yang disandarkan kepada Nabi SAW sama ada perkataan, perbuatan dan pengakuannya.

35 Mawquf ialah hadith yang disandarkan kepada Sahabat, sama ada perkataan, perbuatan, atau pengakuan, sama ada bersambung sanadnya atau pun terputus.

${ }^{36}$ Maqt $\bar{u}$ ' ialah hadith yang disandarkan kepada seorang Tabi'in dan orang sesudah Tabi'in kemudian orang-orang setelah mereka, sama ada perkataan atau perbuatan dan sesamanya.

37 Faizuri Abdul Latif dan Ahmad Faisal Abdul Hamid, "Tradisi Penulisan Hadith dalam Karya Ulama'Melayu: Kajian Terhadap Kitab 'Aqidah alNajin”, Jurnal Usuluddin 30 (2009), 91-110.

38 Muslim bin Ḥajjāj al-Qushayrī al-Naysabūrī, Ṣahīh Muslim (t.tp.: 'Isā al-Bābī al-Halabī wa Syurakah, 1955), 1:14.

39 Muslim, Sahīh Muslim, 14.

40 Muslim bin Hajjāj al-Qushayrī, Șah̄ị Muslim bi Syarh al-Nawāwī (Mesir: Matba'ah Mișriyyah, 1924), 1:88. 
Al-Thawrī juga pernah berkata bahawa sanad adalah senjata orang mukmin, jika pada diri orang mukmin tidak ada senjata maka dengan apa dia akan menghadapi peperangan ${ }^{41}$, al-Awza ‘ $\overline{1}$ mengatakan bahawa hilangnya pengetahuan hadith tidak akan terjadi kecuali jika sanad haditnya hilang ${ }^{42}$. Begitu pentingnya sanad dalam menyampaikan hadith begitu juga dalam penulisan hadith. Kepentingan sanad dan nilainya akan dapat dirasakan oleh orang yang mengkaji rijal sesebuah hadith setelah mengkajinya di dalam kitab-kitab yang menjelaskannya. Kepentingannya adalah seiring dengan kepentingan mengetahui Ittișal ${ }^{43}$ dan Inqița ${ }^{44}$ sesebuah hadith itu, kalau tidak demikian maka sukar atau mustahil untuk membezakan mana hadith yang sahih dan mana hadith yang palsu dan akan beranilah para pendusta untuk merekareka hadith ${ }^{45}$.

Oleh yang demikian, untuk mengetahui semua perkara tersebut perlu adanya kajian takhrīj ${ }^{-46}$ dan dirāsah asānid terhadap sanad-sanad hadith ini, sehingga kita mengetahui kedudukan hadith sebenar, sama ada ianya maqbūl atau mardīd.

\section{ii. Aspek Penggunaan Lafaz dan Sighat dalam Riwayat Hadith} Jadual di atas menunjukkan bahawa Nawawi al-Bantani menggunakan tiga metode iaitu:

Pertama: Menggunakan kaedah penulisan hadith hanya dengan sighāt ruwiya al-Marfū ' ilā al-Nabī, contohnya ${ }^{47}$ :

$$
\text { الله فإنكم لم تقدروه حق قدرعا إلى رسول الله صلى الله عليه وسلم: تفكروا في في آيات الله ولا تفكروا في }
$$

41 Nur al-Dīn al-'Itr, Manhaj al-Naqd fì 'Ulūm al-Hadīth (Damsyik: Dār al-Fikr, 1979), 344.

42 Al-'Itr, Manhaj al-Naqd fì 'Ulūm al-Hadìth, 345.

43 Ittișal bermaksud bersambungnya rangkaian sanad hadith dari awal hingga akhir hadith.

44 Inqițâ' bermaksud terputusnya salah satu atau lebih daripada rangkaian sanad hadith.

45 Maḥmūd al-Ṭaḥhan, Ușūl al-Takhrīj wa Dirāsāt al-Asānid (Riyadh: Maktabah al-Ma'ārif li Nashr wa al-Tawzī', 1996), 139.

46 Takhrijj bermaksud hadith yang dikemukakan oleh pengarang dengan sanadnya sendiri dalam kitabnya.

${ }^{47}$ Nawawi, Nasā'ih al- 'Ibād fì Bayān Alfāz Munabbihat 'alā al-Isti'dad li Yawm al-Ma'ad, 47-51. 


$$
\begin{aligned}
& \text { وفي حديث الطبراني مرفوعا إلى رسول الله صلى الله عليه وسلم: إن من زنا فيه أو } \\
& \text { شرب خمرا لعنه الله ومن في السموات إلى مثله من الحول الثاني. }
\end{aligned}
$$

Kedua: Menggunakan lafaz atau sighat ruwiya dan qāla. Contoh pada ruwiya ${ }^{48}$ :

روي عن النبي صلى الله عليه وسلم أنه قال: استعينوا على الحاجات بالكتمان فإن

$$
\text { كل ذى نعمة محسود. }
$$

Contoh pada sighat qāla ${ }^{49}$ :

$$
\text { خال صلى الله عليه وسلم: ليس خيركم من ترك الدنيا للآخرة ولا الآخرة للدنيا ولكن }
$$

Ketiga: Menggunakan lafaz atau sighat fi al-khabar, contohnya $^{50}$ :

$$
\text { وفي الخبر: تفكر ساعة خير من عبادة ستين سنة. }
$$

Manakala Ihsan al-Jampasi menggunakan lapan metode iaitu:

Pertama: Menggunakan kaedah penulisan hadith dengan menulis lafaz al-ladhī qīl fîh di awal hadith, contohnya ${ }^{51}$ :

$$
\text { الذي قيل فيه: من يرد الله به خيرا يفقه في الدين. }
$$

Kedua: menggunakan lafaz dan sighat 'amala bi-qawlih sallā Allāh 'alayh wa-sallam, contohya ${ }^{52}$ :

عملا بقوله صلى الله عليه وسلم: من أسدى إليكم معروفا فكافؤه فإن لم تكافؤه

$$
\text { فادعوا له. }
$$

Ketiga: Menggunakan lafaz dan sighat qāl sallā Allāh 'alayh wa-sallam, misalnya ${ }^{53}$ :

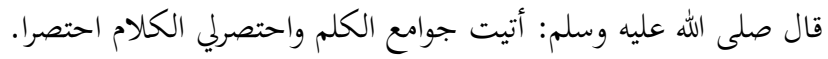

48 Nawawi, Nasā'ih al- 'Ibād fì Bayān Alfāz Munabbihat 'alā al-Isti'dad li Yawm al-Ma'ad, 53.

49 Nawawi, Nasā'ih al- 'Ibād fì Bayān Alfāz Munabbihat 'alā al-Isti'dad li Yawm al-Ma'ad, 56.

50 Nawawi, Nasā'ih al- 'Ibād fì Bayān Alfāz Munabbihat 'alā al-Isti'dad li Yawm al-Ma'ad, 36.

51 Ihsan al-Jampasi, Sirāj al-Ṭālibīn (Beirut: Dār al-Kutub al-'Ilmiyyah, 2000), 5.

${ }^{52}$ Ihsan al-Jampasi, Sirāj al-Tālibìn, 13.

53 Ihsan al-Jampasi, Sirāj al-Ṭālibìn, 19. 
Keempat: Menggunakan lafaz dan sighat 'amal bi-khabar, contohnya $^{54}$ :

$$
\begin{aligned}
& \text { عمل بخبر: كل امر ذي بال لا يبدأ ببسم الله الرحمن الرحيم فهو اقطع. (رواه أبو } \\
& \text { داود وحسنه ابن الصلاح وغيره). }
\end{aligned}
$$

Kelima: Menggunakan lafaz dan sighat qawluh sallā Allāh 'alayh wa-sallam, contohnya ${ }^{55}$ :

$$
\text { قوله صلى الله عليه وسلم: لا تفضلوني عن الأنبياء. }
$$

Keenam: Menggunakan lafaz wa-qad warada, contohnya ${ }^{56}$ :

$$
\text { وقد ورد: أن الملائكة لتضع أجنحتها لطالب العلم. }
$$

Ketujuh: Menggunakan lafaz wa-Sāhib al-Shar' yaqūl, contohnya $^{57}$ :

$$
\text { وصاحب الشرع يقول: تناكحوا تناسلوا. }
$$

Kelapan: Menggunakan lafaz alā tasma' qawluh al-Nabī sallā Allāh 'alayh wa-sallam ${ }^{58}$.

Daripada aspek kedua ini Nawawi al-Bantani dan Ihsan alJampasi sama-sama menggunakan lafaz atau sighat Qāla pada sebahagian awal hadith dalam kitab mereka. Sedangkan lafaz yang lain banyak digunakan oleh Ihsan al-Jampasi dalam kitabnya dan Shaykh Nawawi al-Bantani tidak menggunakannya.

Kaedah penulisan hadith yang menggunakan sighat Ruwiya, Qāla, fì al-Khabar, Qawluhu Nabi saw, sudah boleh diketahui bahawa ia adalah hadith Marfü' tetapi belum diketahui status hukum hadith secara pasti apakah ianya sahih, hasan ataupun da îf. Sedangkan kaedah penulisan hadith dengan sighat atau lafaz yang lain daripada itu maka masih sukar untuk mengetahui status dan sumber asal hadith apakah ianya marf $\bar{u}$ ', mawquf atau maqtū apakah ianya hadith șahĭh, hasan ataupun $d \bar{a}$ 'ĭf, oleh itu perlu diadakan kajian takhrij secara mendalam.

Dalam kaedah penulisan hadith dikenal adanya sighah tamrīe iaitu isyarat akan lemahnya sesebuah hadith yang dibina dengan Majhūl iaitu dengan kata kerja pasif seperti yurwā, yuqāl, yuhk $\bar{a}$, yudhkar, nuqil, qūl, balaghanā, warada, jā'. Sedangkan sighah

\footnotetext{
${ }^{54}$ Ihsan al-Jampasi, Sirāj al-Ṭāilìin, 20.

55 Ihsan al-Jampasi, Sirāj al-Ṭālibìn, 37.

56 Ihsan al-Jampasi, Sirāj al-Ṭālibìn, 42.

57 Ihsan al-Jampasi, Sirāj al-Ṭālibīn, 46.

58 Ihsan al-Jampasi, Sirāj al-Ṭālibìn, 50.
} 
jazam adalah isyarat akan kesahihan atau kehasanan suatu hadith yang dibina dengan ma 'lūm iaitu kata kerja aktif seperti qāl Rasūl Allāh, yaqūl Rasūl Allāh dan 'an Rasūl Allāh ${ }^{59}$.

Al-Nawāwī (pengarang kitab al-Arba'ìn Nawāwì) mengatakan bahawa sighah jazam adalah digunakan untuk hadith sahịh dan hasan dan tidak boleh dipakai pada hadith da îf. Beliau juga mengatakan bahawa Sighat Jazam yang dipakai pada hadith sahīh dan hasan tidak semestinya hadith itu mutlak sahịh dengan keberadaan sighat boleh jadi sebaliknya dan mesti dilihat kepada siapa perawi yang menyandarkan hadith tersebut ${ }^{60}$. Tidak semua berita yang disampaikan oleh Sahabat Nabi dengan sighat di atas adalah hadith Nabi, berita itu ada yang berstatus hadith marfü ' ada yang maqtū' dan ada pula mawqüf. Untuk mengetahui itu perlu adanya penelitian dan analisis takhrijj terhadap hadith tersebut. Daripada keterangan di atas dapat diketahui bahawa Nawawi alBantani dan Ihsan Jampasi telah mengunakan beragam sighat atau lafaz pada permulaan hadith dalam kitab mereka, sama ada sighat jazam mahupun sighat tamrìd, sedangkan lafaz atau sighat yang lain yang banyak digunakan oleh Ihsan Jampasi itu adalah metode beliau sendiri dalam menukilkan dan menuliskan hadith.

Walaupun beliau menggunakan metode sendiri tetapi para penulis hadith perlu menghayati apa yang dikatakan oleh Mạ̣mūd al-Ṭaḥhan iaitu 'bagi penulis hadith mencurahkan kesungguhannya dalam menulis harakat dan titik serta menjaganya dari campur-aduk. Memberikan harakat terutama nama-nama kerana tidak diketahui apa harakat sebelum atau selepasnya. Hendaklah menulis dengan tulisan yang jelas dan sesuai dengan kaedah penulisan pada amnya. Dan hendaklah tidak membuat istilah sendiri dengan istilah khusus seperti singkatan yang tidak diketahui oleh orang ramai ${ }^{61}$,

59 Jalāl al-Dīn 'Abd al-Raḥman bin Abī Bakr al-Suyūṭī, Tadrīb al-Rāwī fì Sharh Taqrīb al-Nawāwwì, taḥqīq: Aḥmad 'Umar Hasim (Beirut: Dār al-Kitāb al'Arabī, 1996), 1-2:250.

${ }^{60}$ Abū Zakariyyā Muḥy al-Dīn al-Nawāwī, al-Majmū’ Sharh al-Muhadhdhab, taḥqīq: Maḥmūd Matrajī (Beirut: Dār al-Fikr, 1996), 1:98.

61 Maḥmūd Ibn Aḥmad al-Ṭaḥhān, Taysīr Muștalah al-Hadīth (Riyadh: Maktabah al-Ma'ärif, 1987), 138. 


\section{iii. Aspek Penyataan Sumber Hadith}

Daripada jadual di atas dapat dikatakan bahawa Nawawi alBantani tidak menggunakan kaedah ini sedangkan Ihsan alJampasi menggunakan dua metode iaitu:

Pertama: Menggunakan kaedah penulisan hadith dengan menyebut kitab dan pengarang kitab dengan memberi huraian bahawa hadith tersebut adalah marfū ‘, contohnya ${ }^{62}$ :

$$
\text { قال: وقد أخرج الترمذي في جامعه حديثا مرفوعا ذكر فيه عن الرب سبحانه وتعالى أنه }
$$

Kedua: Menggunakan kaedah penulisan hadith dengan menulis pengarang kitab yang menyebutkan hadith daripada pengeluar hadith daripada rawi al-A la dan ulama pengeluar hadith serta pendapat ulama tentang status hadith kemudian menjelaskan bahawa hadith tersebut adalah marfī', contohnya ${ }^{63}$ :

$$
\begin{aligned}
& \text { قال العلامة الزبيدي: روي أبو داود في الملاحم والحاكم في الفتن وصححه والبيهقي }
\end{aligned}
$$

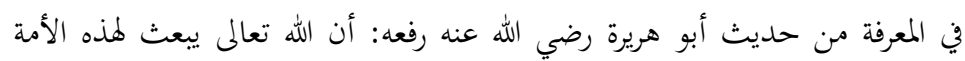

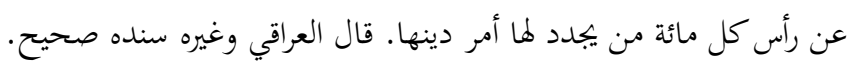

\section{iv. Aspek Penulisan Matan}

Berdasarkan jadual di atas Nawawi al-Bantani menggunakan satu metode penulisan hadith dengan matan, contohnya ${ }^{64}$ :

$$
\text { خصلتان لا شيء أفضل منهما، الإيمان بالله والنفع للمسلمين، وخصلتان لا شيء }
$$

Sedangkan Ihsan al-Jampasi tidak ada menggunakan kaedah tersebut.

\section{v. Aspek Penulisan Makna Hadith}

Daripada aspek penulisan makna Nawawi al-Bantani tidak menggunakan metode ini dalam kitabnya, sedangkan Ihsan al-

${ }^{62}$ Nawawi, Nasā'ih al- 'Ibād fì Bayān Alfāz Munabbihat 'alā al-Isti'dad li Yawm al-Ma'ad, 25.

${ }^{63}$ Nawawi, Nasā'ih al- 'Ibād fì Bayān Alfāz Munabbihat 'alā al-Isti'dad li Yawm al-Ma'ad, 5.

${ }^{64}$ Nawawi, Nasā'ih al- 'Ibād fì Bayān Alfāz Munabbihat 'alā al-Isti'dad li Yawm al-Ma'ad, 27. 
Jampasi menggunakan kaedah iaitu penulisan hadith dengan menyebut maknanya sahaja ${ }^{65}$.

Daripada aspek penulisan hadith dengan matan dan makna, maka keduanya menulis hadith menggunakan matan (Riwāyat bi Lafz). Bezanya Ihsan al-Jampasi menulis hadith kadang-kadang hanya dengan makna (Riwāyat bi al-Ma'nā), manakala Nawawi al-Bantani jarang menulis hadith dengan makna (Riwāyat bi al$M a$ 'nā). Menulis hadith yang hanya menggunakan matan, masih sukar dikesan statusnya, hukumnya dan sumber asalnya lebihlebih lagi yang ditulis hanya dengan makna sahaja. Oleh itu, untuk kaedah ini masih diperlukan kajian takhrīj dan dirāsah asānid untuk mengetahui status hadith tersebut sama ada ianya marfü', mawquf atau maqtū', sama ada șaḥihh, hasan, da 'îf, atau mawdī'. Hadith-hadith yang ditulis dengan matan langsung (diriwayatkan secara laf $z \bar{\imath}$ ) oleh para sahabat sebagai saksi pertama hanyalah hadith yang dalam bentuk sabda dan didengar langsung daripada Nabi SAW. Sedangkan hadith yang tidak dalam bentuk sabda (tidak didengar langsung daripada Nabi) hanya dimungkinkan dapat diriwayatkan secara makna. Kerana hadith yang tidak didengar langsung daripada Nabi adalah kalimat yang berpindah dari satu Sahabat kepada Sahabat yang lain.

Di sini penulis tidak membahaskan tentang periwayatan hadith secara lafaz atau hadith yang ditulis secara matan langsung kerana perkara itu adalah perkara yang sudah diketahui secara meluas. Tetapi di sini penulis membincangkan tentang periwayatan dengan makna yang banyak ditulis oleh Ihsan alJampasi. Para sahabat Nabi kebanyakan membolehkan untuk meriwayatkan hadith secara makna. Di antara mereka adalah 'Alī bin Abī Țālib, Ibn 'Abbās, Anas bin Mālik, Abū Darda', 'Abd Allāh bin Mas'ūd, 'A' 'ishah manakala daripada Tabi' in seperti Hasan al-Bașri, al-Shi'bī, 'Amru Ibn Dinār, Ibrāhīm al-Nakha'ī, Mujāhid dan 'Ikrimah ${ }^{66}$. Sebahagian kecil daripada kalangan sahabat tetap berpegang pada periwayatan dengan lafẓi di antaranya ialah 'Umar bin al-Khattab, 'Abd Allāh bin 'Umar dan Zayd bin al-Arqām, ulama yang lain yang tetap berpegang dengan periwayatan hadith secara lafaz ialah Muhammad bin Sīrin, Raja'

65 Ihsan al-Jampasi, Sirāj al-Ṭālibīn, 42.

${ }^{66}$ Muḥammad 'Ajjāj al-Khāțib, Ușūl al-Hadīth 'Ulumuhu wa Muștalahuhu, 130132. 
bin Haywah, Qāsim bin Muḥammad, Tha'lab bin Nahwi, Abū Bakar al-Rā $\bar{z}{ }^{67}$. Walaupun demikian mereka yang tetap berpegang pada periwayatan secara lafaz tidaklah melarang secara tegas periwayatan hadith secara makna. Ulama mempersoalkan boleh tidaknya selain Sahabat Nabi meriwayatkan hadith secara makna. Abū Bakar al-'Arabī berpendapat bahawa selain sahabat Nabi tidak diperbolehkan meriwayatkan hadith secara makna. Para sahabat Nabi dibolehkan meriwayatkan hadith secara makna kerana mereka memiliki pengetahuan bahasa Arab yang tinggi (alFasāhah wa al-Balāghah). Mereka juga menyaksikan langsung keadaan dan perbuatan Nabi SAW. Kebanyakan ulama membolehkan riwayat hadith dengan makna dengan beberapa syarat yang disepakati di antaranya ialah ${ }^{68}$ :

1. Bahawa yang boleh meriwayatkan hadith secara makna hanyalah mereka yang benar-benar memiliki pengetahuan bahasa Arab yang mendalam. Dengan demikian periwayatan matan hadith akan terhindar daripada kekeliruan, contohnya menghalalkan yang haram atau sebaliknya.

2. Periwayatan dengan makna dilakukan kerana sangat terpaksa misalnya kerana lupa susunan secara harfiah.

3. Bahawa yang diriwayatkan dengan makna bukanlah sabda Nabi SAW dalam bentuk bacaan yang sifatnya ta'abbudi, contohnya zikir, doa, azan dan sebagainya serta bukan dalam bentuk Jawāmi' al-Kalim.

4. Periwayat yang meriwayatkan hadith dengan makna atau yang mengalami keraguan akan susunan matan hadith yang diriwayatkan agar menambah kata-kata (aw kamā qāla, aw nahwu hadha) atau yang semakna dengannya setelah menyatakan matan hadith yang bersangkutan.

5. Kebolehan periwayatan hadith secara makna hanya terbatas pada masa sebelum dibukukannya hadith Nabi secara rasmi, sesudah masa pembukuan hadith maka periwayatan hadith harus secara $\operatorname{laf}_{z i} i^{9}$.

67 Al-Khāțib, Ușūl al-Hadìth 'Ulumuhu wa Muștalahuhu, 127-128, al-Ḥasan bin 'Abd al-Raḥman al-Ramahurmuzi, al-Muhaddìth al-Fāṣil Bayna al-Rāwì wa al-Wā' '̄ (cet. 1, Kaherah: Dār al-Bayān, 1971), 686.

68 Al-Ramahurmuzi, al-Muhaddīth al-Fāṣil Bayna al-Rāwī wa al-Wa'i, 533-536.

69 Abū 'Umar 'Uthmān bin 'Abd al-Raḥman Ibn Șalaḥ, 'Ulūm al-Hadīth (Madinah: Maktabah al-'Ilmiyyah, 1972), 190-192. Abū Zahwī Muḥammad 
Adanya syarat-syarat tersebut menandakan bahawa periwayatan hadith secara makna walaupun dibolehkan oleh ulama tetapi praktiknya tidak dibiarkan begitu saja, ertinya para periwayat tidak bebas begitu saja dalam melakukan periwayatan secara makna. Kemudian ulama hadith menimbulkan soalan tentang boleh tidaknya periwayat hadith atau menulis hadith dengan meringkas matan hadith. Ada ulama yang melarangnya dan ada yang membolehkannya tanpa syarat dan ada yang membolehkannya dengan syarat-syarat tertentu. Pendapat yang terakhir ini banyak diikuti oleh ulama hadith. Syarat-syarat yang dimaksudkan itu adalah:

1. Bahawa yang melakukan ringkasan itu bukanlah periwayat hadith yang bersangkutan.

2. Apabila ringkasan dilakukan oleh periwayat hadith, maka sudah harus ada hadith yang dikemukakannya secara sempurna.

3. Tidak dipotong kalimat yang mengandungi kata pengecualian (al-Istisn $\bar{a}$ ), syarat, al-ghāyah, dan yang seumpamanya.

4. Keringkasan itu tidak termasuk petunjuk dan penjelasan yang terkandung dalam hadith yang bersangkutan.

5. Bahawa yang melakukan ringkasan haruslah orang yang benarbenar telah mengetahui kandungan hadith yang bersangkutan ${ }^{70}$. Ulama berbeza pendapat tentang periwayatan hadith dengan cara meringkaskan matan tetapi pendapat yang cukup hati-hati adalah pendapat yang membolehkannya dengan catatan dipenuhi syarat-syaratnya.

Secara ringkasnya persamaan dan perbezaan metode penulisan hadith dalam kitab Nașā'ih al-'Ibād oleh Nawawi alBantani dan Sirāj al-Tāilibìn oleh Ihsan al-Jampasi dapat dilhat dalam jadual berikut:

Muhammad, al-Hadīth wa al-Muhaddīthūn (Mesir: Matba'ah al-Miṣr, t.t.), 201-205.

70 Ibn Salah, 'Ulūm al-Hadīth, 192-194, Abū Zakariyyā Yaḥyā bin Sharaf, Taqrīb al-Nawāwī fì Ușūl al-Hadīth (Kaherah: t.p., t.t.), 25-26. 
Jadual 2.0: Jadual persamaan dan perbezaan metode penulisan hadith dalam kitab Nașà'ih al- 'Ibād oleh Nawawi al-Bantani dan Sirāj al-Tâlibìn oleh Ihsan al-Jampasi

\begin{tabular}{|c|c|c|c|}
\hline No & 180 & Persamaan & Perbezaan \\
\hline 1 & $\begin{array}{l}\text { Penu- } \\
\text { lisan } \\
\text { sanad. }\end{array}$ & $\begin{array}{l}\text { Nawawi al-Bantani dan } \\
\text { Ihsan al-Jampasi sama- } \\
\text { sama menggunakan kaedah } \\
\text { penulisan hadith tanpa } \\
\text { sanad dan menyatakan } \\
\text { mukhrij al-hadith tersebut. }\end{array}$ & 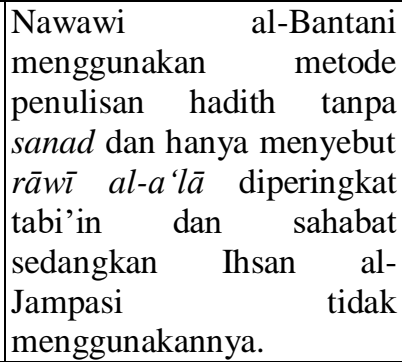 \\
\hline 2 & $\begin{array}{l}\text { Peng- } \\
\text { gunaan } \\
\text { lafaz dan } \\
\text { sighat } \\
\text { dalam } \\
\text { riwayat } \\
\text { hadith. }\end{array}$ & $\begin{array}{l}\text { Nawawi al-Bantani dan } \\
\text { Ihsan al-Jampasi sama- } \\
\text { sama menggunakan lafaz } \\
\text { atau shigat qāla pada } \\
\text { sebahagiaan awal hadith } \\
\text { dalam kitab mereka. }\end{array}$ & 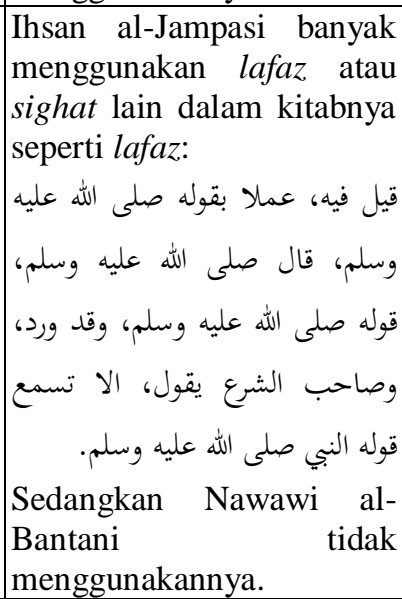 \\
\hline 3 & $\begin{array}{l}\text { Penya- } \\
\text { taan } \\
\text { sumber } \\
\text { hadith. }\end{array}$ & $\begin{array}{l}\text { Tiada dijumpai persamaan } \\
\text { dalam metode ini. }\end{array}$ & $\begin{array}{l}\text { Ihsan al-Jampasi } \\
\text { menggunakan kaedah ini } \\
\text { dalam kitabnya sedangkan } \\
\text { Nawawi al-Bantani tidak } \\
\text { menggunakannya. }\end{array}$ \\
\hline 4 & $\begin{array}{l}\text { Penu- } \\
\text { lisan } \\
\text { matan } \\
\text { dan } \\
\text { ma'na } \\
\text { hadith. }\end{array}$ & \begin{tabular}{ll}
\multicolumn{3}{l}{ Kedua ulama di atas sama- } \\
sama menulis & hadith \\
menggunakan & matan \\
Riwāyat bi al-Lafz. &
\end{tabular} & 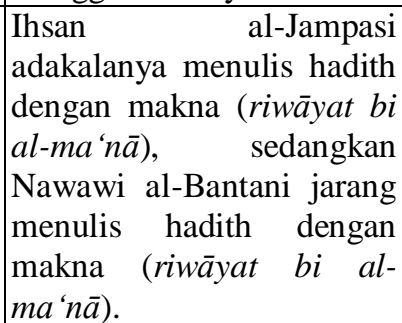 \\
\hline
\end{tabular}




\section{Penutup}

Nawawi al-Bantani dan Ihsan al-Jampasi telah memberikan impak besar dalam mengembangkan ilmu hadith di Nusantara. Keduanya merupakan ulama yang aktif dalam menulis karya-karya besar yang mencakupi pelbagai disiplin ilmu Islam. Karya mereka masih banyak digunakan di Indonesia dan menjadi rujukan hingga ke hari ini. Di kalangan penuntut ilmu di Nusantara, kedua-dua tokoh ulama tersebut tidak hanya dikenali sebagai penulis kitab sahaja, bahkan dikenali sebagai mahaguru sejati. Jasa Nawawi al-Bantani dan Ihsan al-Jampasi telah berjaya meletakkan landasan kepada ilmu hadith dan batasan-batasan periwayatan hadith di alam Nusantara. Penyampaian dan pengajaran hadith kepada masyarakat Islam bagi kedua-dua tokoh tersebut menekankan pada nilai-nilai pengamalan hadith dengan melakukan penapisan hadithhadith yang sesuai diamalkan masyarakat. Manakala sanad dan tarī $q$ hadith tidak diceritakan secara mendalam. Namun demikian, bukanlah keduanya mengabaikan tanggungjawab pemuliharaan hadith daripada kepalsuan untuk diajarkan kepada masyarakat.

Justeru, metode keduanya memudahkan pengamalan hadith tanpa menyusahkan masyarakat awam untuk menapis hadith sama ada yang șahih mahupun yang palsu. Pemikiran metode penulisan hadith keduanya masih relevan diamalkan dalam dunia perkembangan hadith pada ketika ini, kerana ulama hadith tidak menentang cara penyampaian hadith yang dibuat oleh Nawawi dan al-Jampasi. Metode yang diperkenalkan keduanya juga dapat mempertahankan dan melestarikan hadith-hadith Nabi daripada dibuang dan ditinggalkan. Ianya merupakan kerangka kerja besar penjagaan hadith Nabi yang layak untuk dihargai dan dipertimbangkan dalam mengurangi ketegangan dikalangan pengkaji hadith di Nusantara.

\section{Rujukan}

Agus Sutopo. "Sumbangan Nawawi al-Bantani dalam Bidang Hadis: Kajian Terhadap Kitab Tanqih al-Qawl". Disertasi, Jabatan al-Quran dan al-Hadith, Akademi Pengajian Islam, Universiti Malaya, 2008.

Al-'Itr, Nur al-Dīn. Manhaj al-Naqd fì 'Ulūm al-Hadīth. Damsyik: Dār al-Fikr, 1979. 
Al-Khātib, Muḥammad 'Ajjāj. Ușūl al-Hadīth 'Ulumuh wa Muștalahuh. Cet. ke-3, Beirut: Dār al-Fikr, 1975.

Al-Nawāwī, Abū Zakariyyā Muḥy al-Dīn. Al-Majmū' Sharh alMuhadhdhab, taḥqīq: Maḥmūd Matrajīi. Beirut: Dār al-Fikr, 1996.

Al-Nawāwī, Abū Zakariyyā Yahyā bin Sharaf. Taqrīb al-Nawāwō fì Ușül al-Hadīth. Kaherah: t.p., t.t.

Al-Naysabūrī Muslim bin Ḥajjāj al-Qushayrī. Șaḥịh Muslim. T.tp.: 'Isā al-Bābī al-Halabī wa Syurakah, 1955.

Al-Qushayrī, Muslim bin Hajjāj. Șaḥịh Muslim bi Syarh alNawāwī. Mesir: Matba'ah Mișriyyah, 1924.

Al-Ramahurmuzi, al-Ḥasan bin 'Abd al-Raḥman. Al-Muhaddīth al-Fāṣil Bayna al-Rāwī wa al-Wa'i. Cet. 1, Kaherah: Dār alBayān, 1971.

Al-Suyūṭī, Jalāl al-Dīn 'Abd al-Raḥman bin Abī Bakr. Tadrīb alRāwì fì Sharh Taqrīb al-Nawāwō, tạ̣qīq: Ahmad 'Umar Hasim. Beirut: Dār al-Kitāb al-'Arabī, 1996.

Al-Ṭaḥhān, Maḥmūd Ibn Aḥmad. Taysīr Muștalah al-Hadīth. Riyadh: Maktabah al-Ma‘āifif, 1987.

Arif Chasanul Muna. "Penulisan Kitab al-Ṣabat dalam Kajian Hadis di Nusantara". Kertas pembentangan, $1^{\text {st }}$ ASILHA International Conference: Hadith Studies and Its Contribution for Indonesia and Muslim World di UIN Sunan Kalijaga Yogyakarta, 26 Oktober 2016.

Asnawi. "Pemikiran Shaykh Nawawi Tentang Ayat Qada' dan Qadar dalam Kitab Tafsirnya Marah Labib". Disertasi IAIN Syarif Hidayatullah, Jakarta, 1989.

Badri Khaeruman. "Perkembangan Hadis di Indonesia pada Abad XX". Diroyah: Jurnal Studi Ilmu Hadis 1, no 2 (March 2017), 187-202.

Bruinesen, Martin Van. Terj. Kitab Kuning. Pesantren dan Tarekat. Bandung: Mizan, 1995.

Chaidar. Sejarah Pujangga Islam Shaykh Nawawi Banteni. Jakarta: CV Sarana Utama, 1978.

Ensiklopedia Islam Indonesia. Jakarta: Depdikbud Indonesia, 1993.

Ensiklopedia Islam. Cet. ke 3, Jakarta: PT, Ichtiar Baru Van Hoeve, 1994. 
Fachrul Avivy, Ahmad Levi dan Jawiah Dakir. "Methodology of Writing Hadith in the Works of Muhammad Nawawi AlBantani" Journal of Applied Sciences Research 8, issue 4 (April 2012), 2187-2192.

Faizuri Abdul Latif dan Ahmad Faisal Abdul Hamid. "Tradisi Penulisan Hadith dalam Karya Ulama'Melayu: Kajian Terhadap Kitab 'Aqidah al-Najin”. Jurnal Usuluddin 30 (2009), 91-110.

Ibn Șalaḥ, Abū 'Umar 'Uthmān bin 'Abd al-Raḥman. 'Ulūm alHadith. Madinah: Maktabah al-'Ilmiyyah, 1972.

Ihsan al-Jampasi. Pengantar Kitab Kopi dan Rokok. Yogyakarta: Pustaka Pesantren, 2009.

Ihsan al-Jampasi. Sirāj al-Ṭălibīn. Beirut: Dār al-Kutub al'Ilmiyyah, 2000.

Ishak Haji Suliaman. "Metodologi Penulisan Bulugh al-Marām Sebagai Kitab Hadīth al-Aḥkām”. Jurnal Usuluddin 10 (1999), $1-20$.

Johns, A.H. Qur'anic Exegesis in the Malay Word. T.tp.: t.p, .t.t.

Kamus Dewan. Edisi ke-3, Kuala lumpur: Dewan Bahasa dan Pustaka, 2002.

Karel A. Steenbrink. Beberapa Aspek Tentang Islam di Indonesia Abad ke 19. Jakarta: Terjemahan Bulan Bintang, 1984.

Ma'luf, Louis. Munjid fi al-A 'lam. Cet. ke 26, t.tp: t.p, t.t.

Mạ̣mūd. al-Ṭaḥhan, Ușūl al-Takhrīj wa Dirāsāt al-Asānid. Riyadh: Maktabah al-Ma'ārif li Nashr wa al-Tawzī', 1996.

Muhammad Nawawi Banteni. Nasā'ih al-'Ibād fi Bayān Alfāz Munabbihat 'alā al-Isti'dad li Yawm al-Ma'ad. Indonesia: Dār Ihta' al-Kutub al-'Arabiyyah, t.t.

Muḥammad, Abū Zahwī Muḥammad. Al-Hadīth wa alMuhaddīthūn. Mesir : Matba'ah al-Mișr, t.t.

Parlindungan Simbolon. "Metode Penulisan Hadith dalam Tafsir Bahasa Melayu: Kajian Perbandingan Antara Tafsir al-Misbah dan Tafsir Pedoman al-Muttaqin”. Disertasi, Universiti Malaya, 2013.

Rafi'uddin Ramli. Sejarah Hidup dan Silsilah Keturunan Shaykh Nawawi Banteni. Banten: Yayasan Nawawi Tanara, t.t.

Yusuf 'Allan Sarkis. Mu'jam al-Matbü'ah al-'Arabiyyah wa alMu'arrabah. Kaherah: Maktabah al-Thaqafah al-Dīniyyah, t.t. 